\title{
Produksi Kerajinan Sarana Upacara Dan Gaya Hidup Religius Masyarakat Gianyar
}

\author{
Ni Kadek Karuni ${ }^{1}$, I Wayan Suardana ${ }^{2}$, I Made Suparta ${ }^{3}$ \\ ${ }^{1.2 .3}$ Program Studi Kriya Seni, Fakultas Seni Rupa dan Desain, Institut Seni Indonesia Denpasar, Indonesia
}

\author{
kadekkaruni@ymail.com
}

\begin{abstract}
Masyarakat Bali adalah masyarakat religius, tiada hari tanpa aktivitas keagamaan. Di bawah kungkungan globalisasi dengan kebebasan yang sangat terbuka tidak bisa menggoyahkan sikap religius masyarakat, bahkan justru menjadi semakin melekat kuat di hati masyarakat. Kuatnya nilai-nilai religius dengan beranekaragam kegiatan adat dan agama menyebabkan rasa ritual menjadi bagian dari gaya hidup masyarakat Gianyar dengan segala aktivitasnya. Untuk mendukung aktivitas tersebut, tentunya membutuhkan berbagai bentuk dan jenis produk sarana upacara dengan segala fungsinya. Meningkatnya kebutuhan akan sarana upacara untuk mendukung ritual menggugah para perajin mengembangkan kreativitas menciptakan karya baru yang lebih artistik dan menarik. Produksi seni kerajinan sarana upacara akhirnya mengalami dinamika yang cukup pesat dengan menawarkan model dan fungsi yang bervariatif. Tujuan penulisan ini untuk mendalami dinamika produksi seni kerajinan sarana upacara dalam mendukung gaya hidup religius masyarakat Gianyar. Mengacu pada metode penelitian kualitatif dengan analisis deskriptif analitik melalui pendekatan perubahan sosial. dengan pengumpulan data melalui observasi, wawancara, dan dokumentasi. Hasil penelitian menunjukan bahwa orientasi kehidupan religius masyarakat masih sangat kental yang terimplementasi pada meningkatnya aktivitas upacara adat dan agama. Ritual menjadi bagian dari gaya hidup masyarakat untuk menunjukan jati diri dan kedudukan sosial yang lebih tinggi, didukung dengan penggunaan sarana upacara yang mewah dan elegan. Selain untuk mempersembahkan yang terbaik dan terindah pada Yang Maha Kuasa, sarana upacara menjadi standar kehidupan sosial masyarakat sebagai seorang yang berbudaya dan beriman. Hal ini berdampak pada dinamika produksi kerajinan sarana upacara semakin meningkat dan dapat menambah ekonomi perajin. Tulisan ini dapat dijadikan sumber referensi berkaitan dengan dinamika produksi seni kerajinan sarana upacara dengan keanekaragaman bentuk dan fungsinya.
\end{abstract}

Kata kunci: gaya hidup, religius, dan sarana upacara

\section{The Production Of Ceremonial Crafts And The Lifestyle Of Religious Communities In Gianyar}

Balinese is a religious community, known as no day without religious activity. In globalization era in which it is surrounded with freedom, it cannot affect religious attitude of Balinese; in addition, it even become stronger in their hearts. The strength of religious values with various traditional and religious activities make rituals become a part of lifestyle with all their activities in Gianyar. To support these activities, of course, it requires various forms and types of products, especially ceremonial equipment with all its functions. Craft production of ceremonial equipment is increasing by offering a variety of models and functions. The increasing needs for ceremonial equipment in supporting the ritual influence craftsmen to develop their creativity to create new products that were more unique, artistic, and interesting. In addition, the objective of the present research was to deeply learn dynamic production of craft ceremonial equipment in supporting the lifestyle of religious communities in Gianyar. The research used a qualitative method with analytic descriptive analysis through a social change approach. Data collection was through observation, interviews, and documentation. The results showed that the orientation of the religious life of the community was still very strong which was implemented in the increasingly lively activities of traditional and religious ceremonies. Rituals became a part of people's lifestyles in order to show a higher identity and social position in which it was supported by the use of luxurious and elegant ceremonial equipment. In addition, in order to offer the best and most beautiful offerings to the God, the ceremonial means became the standard of social life of the community as a cultured and religious person. This had an impact on the dynamics of the production of Balinese ceremonial equipment in which it might increase the economy of artisans. This research was expected to be used as reference related to the dynamics of the art production of ceremonial equipment with a variety of forms and functions.

Keywords: lifestyle, religious, and ceremony equipment 


\section{PENDAHULUAN}

Belakangan ini animo masyarakat untuk melaksanakan upacara sangat tinggi untuk mempersembahkan segala sesuatu sebagai rasa syukur atas rahmat yang telah diberkahi Hyang Maha Kuasa. Besar kecilnya persembahan tidak menjadi ukuran, semuanya tergantung pada makna dan fungsi upacara tersebut. Suatu hal yang menjadi landasan persembahan pada intinya dilaksanakan berdasarkan pada keyakinan rasa tulus iklas, tanpa pamerih, sesuai dengan sastra agama, serta tidak menyimpang dengan norma-norma yang ada.

Meningkatnya aktivitas upacara tidak dibarengi dengan pemahaman nilai dan makna upacara secara mendalam, sehingga banyak pelaksanaan upacara tidak sesuai dengan tujuan dan maknanya. Masyarakat tertalu mementingkan bentuk upacara, tetapi mereka tidak memahami inti sarinya, sehingga upacara hanya sebagai aktivitas tradisi yang harus dilaksanakan.

Kurangnya pemahaman masyarakat pada tujuan dan fungsi upacara, bermuara pada pelaksanaan upacara memiliki fungsi tambahan yaitu tidak semata sebagai persembahan yang tulus iklas, tetapi bermotivasi lain untuk menunjukan stratifikasi sosial pada masyarakat. Banyak masyarakat memanfaatkan upacara untuk menunjukan status sosial dengan melaksanakan upacara besar dan mewah, penampilan menjadi bagaian yang paling utama. Sarana upacara yang dapat dibuat secara sederhana, dikembangkan dengan tampilan yang sangat besar dan eksklusif dan pada akhirnya menghabiskan biaya yang cukup besar Kebiasaan ini menjadi semakin membudaya di tengah masyarakat dan bila tidak mengikuti, merasa ketakutan apabila upacara yang dilaksanakan dinilai kurang baik terutama yang berhubungan dengan penampilan. Pelaksanaan upacara menjadi sangat sensitif selalu menjadi pembicaraan baik atau buruknya pelaksanaan upacara tersebut.

Aktivitas upacara tidak semata menjadi ajang untuk menunjukan status sosial masyarakat, tetapi juga dimanfaatkan sebagai ajang berpenampilan secara personal oleh masyarakat pendukungnya. Ketika upacara dilaksanakan, masyarakat akan berpenampilan yang menarik dengan pakaian dan tata rias yang ekslusif. Pelaksanaan upacara menjadi ajang modis, terutama oleh kaum perempuan dengan segala penampilan yang menawan.

Belakangan ini, aktivitas religius dijadikan ajang kontestasi sosial dan gaya hidup oleh masyarakat pendukungnya. Aktivitas upacara menjadi ajang penampilan di balik kewajiban untuk melakukan persembahan. Suasana religius terbungkus oleh penampilan yang eksotik, larut dan bercampur dengan suasana kusuk dan khidmat. Bersolek menjadi bagian yang tak terpisahkan dengan aktivitas upacara dengan keyakinan untuk menghadap Hyang Kuasa. Sebuah pemikiran yang tidak salah, ngayah harus dilakukan dengan jiwa yang tulus iklas dengan penampilan yang sopan dan rapi. Permasalahannya adalah semua dilakukan secara berlebihan yang pada intinya hanya untuk menunjukan diri seseorang memiliki stratifikasi kehidupan sosial yang mapan.

Gaya hidup religius tidak sebatas pada penampilan diri secara fisik, tetapi juga harus didukung oleh penggunaan sarana upacara yang unik dan artistik. Penggunaan sarana upacara yang eklusif merupakan bagian yang tak terpisahkan. Percaya diri seseorang akan lebih mantap apabila membawa sarana upacara yang mewah dan elegan untuk sembahyang ke Pura. Tuntutan untuk mendukung penampilan dalam aktivitas upacara, kebutuhan sarana upacara yang artistik semakin meningkat dan menjadi peluang bagi perajin untuk mengembangkan kreativitasnya dalam menciptakan bentuk sarana upacara yang semakin variatif. Produksi kerajinan sarana upacara mengalami dinamika yang semakin meningkat dan berkembang di beberapa wilayah di Bali dengan menawarkan keanekaragaman bentuk dan fungsi. Di berbagai wilayah di Bali bermunculan sentra-sentra seni kerajinan sarana upacara dengan menggunakan berbagai material seperti kayu, bambu, rotan, daun lontar, fiberglass, baik dalam bentuk ukiran, bubutan, anyaman, kolase, dan cetakan. Dari fenomena yang dipaparkan di atas, ada beberapa permasalahan yang perlu dibahas dalam penelitian ini yaitu; 1. Bagaimana dinamika produksi sarana upacara dalam mendukung gaya hidup religius masyarakat Bali? 2. Bagaimana peranan sarana upacara dalam mendukung gaya hidup religius masyarakat Bali?. Penelitian ini dilakukan dengan tujuan agar dapat mengetahui gaya hidup masyarakat Bali dalam melakukan aktivitas upacara adat dan agama, serta mengetahui secara mendalam pengaruh gaya hidup religius dalam meningkatkan produktivitas seni kerajinan sarana upacara yang ada di Bali. Melalui penelitian ini diharapkan dapat memberikan informasi pada masyarakat dan pemerintah bahwa seni kerajinan sarana upacara perlu tetap dikembangkan dengan berbagai kreasi dalam usaha mendukung gaya hidup religius masyarakat. Hasil penelitian ini akan sangat bermanfaat bagi kalangan akademik seni rupa khususnya seni kriya sebagai sumber studi pembelajaran, selain dalam penciptaan karya, juga dalam proses pemasaran pada era global yang sangat kompetitif.

\section{KAJIAN SUMBER}

Seni kriya dan kerajinan Indonesia memiliki tiga mod- 
al dasar yaitu, potensi bahan baku yang melimpah, tenaga kerja yang terampil, dan potensi budaya yang unik dan beragam, sehingga dapat menghasilkan produk yang khas. Dalam usaha mendapatkan jaringan pasar yang luas, produk perlu dirancang sesuai dengan gejala dinamika yang terjadi di masyarakat. Produk harus dibuat sesuai dengan target segmen konsumen yang dituju. Untuk itu pemahaman serta pengertian yang dalam pada aspirasi serta kebutuhan masyarakat menjadi suatu keharusan. Diperlukan disain produk yang tepat dari berbagai segi, baik rupa, fungsi, teknik, maupun bahan yang digunakan (Anas, 1999: 5). Demikian juga halnya dengan situasi masyarakat Bali saat ini yang banyak membutuhkan kerajinan sarana upacara dengan berbagai bentuk dan fungsi merupakan peluang yang sangat terbuka bagi perajin untuk meningkatkan kreativitasnya dalam usaha mendukung gaya hidup masyarakat yang semakin konsumtip.

Gaya hidup adalah salah satu mekanisme perbedaan sosial yang melalui masyarakat dibedakan atas kelompok-kelompok gaya hidup yang masing-masing membangun identitas kelompoknya dalam rangka membedakan dengan identitas kelompok lainya (Piliang, 2011: 247). Dewasa ini masyarakat Bali memiliki antusiaisme untuk menunjukan identitas gaya hidup yang banyak dikaitkan dengan kehidupan sosial masyarakat dengan segala aktifitasnya.

Terdapat beberapa kecendrungan gaya hidup lain yang hidup di masyarakat yang arahnya justru berseberangan dengan ideologi konsumerisme, dengan munculnya kelompok kepercayaan keagamaan sebagai landasan kehidupan sosial. Mereka mengatur sistem objek dan sistem simbolnya sendirisesuai dengan kepercayaan yang dianutnya (Piliang, 2011: 252). Kondisi ini sesuai dengan apa yang terjadi di Bali, yang mana aktivitas religius menjadi gaya hidup baru masyarakat dan menyebar luas ke seluruh daerah di Bali. Yang sangat menarik adalah aktivitas tradisi dalam kemasannya selalu dikombinasi dengan gaya hidup modern yang lebih eksotik dan elegan. Kombinasi gaya hidup modern dalam aktivitas tradisi, menjadikan penampilan lebih menonjol dari makna religius. Tradisi terbungkus oleh penampilan kulit luar yang serba tergarap dengan serius dan sempurna.

Dalam usaha untuk mendukung gaya hidup religius, masyarakat mulai mengabaikan konsep dan tatanan sastra-sastra agama dalam melaksanakan upacara, sehingga menimbulkan kerancuan dan penapsiran berbeda. Pemahaman kerangka dasar agama yang kurang, menyebabkan sering terjadinya penyimpangan dalam setiap upacara terutama dalam penampilan diri yang terkesan berlebihan dan tidak pada tempatnya
(Subawa, 2012: 54).

Prilaku sangat menonjol belakangan ini penampilan yang berlebihan bagi perempuan Bali dalam melakukan aktivitas adat dan agama. Perempuan Bali selalu kreatif untuk menampilkan diri dengan pakaian kebaya yang lengkap (Soethama, 2011: 231). Hal ini merupakan prilaku perempuan Bali dan menjadi gaya hidup religius telah masuk pada semua lapisan masyarakat Bali.

Acara adat dan agama menjadi peluang menonjolkan daya pikat kewanitaan (Soethama, 2011: 232). Dibalik konsentrasi ngayah, mereka selalu ingin menonjolkan diri dengan penampilan yang eksotis. Kondisi ini tidak terlepas dari pengaruh modernisasi yang semakin menawarkan nilai-nilai baru, baik dalam produk maupun tingkah laku. Didukung dengan berbagai produk baru, terutama kain kebaya dengan menawarkan model dan gaya yang bervariatif peluang yang sangat terbuka untuk pengembangan mode, sehingga lahirlah berbagai gaya busana yang seksi dan menarik.

Perkembangan trend mode memang tidak bisa dicegah, Hal ini merupakan gaya hidup religius masyarakat Bali, menampilkan sikap yang berlebihan dan tidak pada tempatnya, sehingga nilai religius menjadi hambar dan tidak suci.

Gaya hidup religius tidak saja berhubungan dengan penampilan secara fisik, tetapi juga penggunaan sarana lainnya yang dianggap sangat menentukan stratafikasi kehidupan sosial. Pergi ke Pura dengan penampilan yang serba "wah", serta sarana upacara yang dihaturkan dan digunakan dari produk impor. Suatu hal yang wajar, tetapi untuk hal yang berhubungan dengan ritual-spiritual, kemegahan dan kemewahan akan sangat nista apabila tidak dibarengi dengan kesucian dan ketulusan hati (Widana, 2012: 241).

Sarana upacara menjadi bagian pencitraan masyarakat sebagai seorang yang berbudaya dan religius. Dalam dunia kehidupan kontemporer dan era reformasi dewasa ini, pencitraan dalam pembentukan gaya hidup sangat penting dalam menciptakan perkembangan dunia citra itu sendiri ke arah bentuk, teknik dan penampilan yang semakin kompleks (Piliang, 2011:317).

Kebutuhan sarana upacara yang semakin meningkat menjadi peluang yang sangat terbuka bagi perajin untuk berkreasi lebih inovatif dalam berkarya. Perajin sangat jeli untuk menciptakan sesuatu yang berbeda dan sesuai dengan selera masyarakat. Dalam situasi seperti ini, ternyata seni kerajinan secara dinamik 
segera dapat dikembangkan sesuai dengan minat konsumen, terbukti dengan berkembangnya objek-objek kerajinan tertentu yang dipandang memiliki peluang pasar yang menguntungkan. Kerajinan kayu, bambu, rotan, kulit, segera menarik minat investor (pribumi maupun asing) untuk menanamkan modalnya bagi pengembangan industri kecil dan kerajinan tangan (Gustami, 1991, 8).

\section{METODE PENELITIAN}

Penelitian ini menggunakan metode kualitatif yaitu pengamatan, wawancara, dan penelaahan dokumen. Metode ini digunakan karena lebih mudah berhadapan dengan kenyataan, menyajikan secara langsung hubungan antara peneliti dan responden, lebih peka dan lebih dapat menyesuaikan diri pola-pola nilai yang dihadapi (Moleong, 2013: 10). Teknik Pengumpulan data penelitian secara maksimal ditempuh melalui studi pustaka, observasi, wawancara, dandokumentasi. Analisis data meliputi berbagai tahapan: Pertama identifikasi data, mengumpulkan data verbal dan data visual, baik yang diperoleh melalui studi pustaka, observasi, maupun wawancara. Kedua klasifikasi data yaitu memilih atau mengelompokkan data yang telah teridentifikasi sesuai dengan jenis dan sifat data. Ketiga seleksi data yaitu menyisihkan data-data yang tidak relevan dan kurang berkontribusi terhadap kebutuhan dalam pembahasan pokok. Tahap keempat melakukanan analisis sesuai dengan teori yang telah ditetapkan, dengan menggunakan analisis kualitatif analitik.

Teori yang sangat tepat untuk membahas masalah ini adalah teori perubahan sosial. Wilbert Moore dalam Gunawan (2014) menjelaskan bahwa perubahan sosial sebagai perubahan penting dari struktur sosial yaitu pola-pola dan interaksi sosial yang menyangkut norma, nilai dan gejala kultural. Soemandjan dalam Gunawan (2014) menjelaskan bahwa perubahan sosial pada dasarnya sangat sulit dipisahkan dengan perubahan kultural atau budaya. Munculnya gaya hidup religius masyarakat Bali tidak terlepas dari perubahan budaya dan pola-pola prilaku kehidupan masyarakat yang dipengaruhi oleh modernisasi secara kontinyu dan terus-menerus yang melanda budaya tradisi dan beralkuturasi melahirkan sebuah budaya baru yang menyatu dan harmoni. Kehidupan sosial masyarakat akan selalu mengalami perubahan seiring dengan perubahan pola pikir dan tingkah laku masyarakat pendukungnya.

\section{PEMBAHASAN}

Dewasa ini Seni kerajinan sarana upacara memiliki peluang yang sangat besar untuk dikembangkan di tengah masyarakat. Hal ini menjadi peluang yang sangat terbuka bagi para perajin untuk meningkatkan produksi dan memasarkan pada masyarakat konsumen. Produksi seni kerajinan sarana upacara semakin mengalami dinamika yang sangat pesat dan berkembang di berbagai wilayah dengan munculnya sentra-sentra kerajinan rumah tangga, maupun usaha kerajinan yang lebih besar. Penjualan seni kerajinan sarana upacara semakin bertebaran, di sepanjang jalan utama banyak toko penjual berbagai bentuk dan jenis seni kerajinan sarana upacara yang bervariatif. Di pasar-pasar tradisional dan supermarket juga sudah mulai muncul lapak-lapak yang menjual berbagai kebutuhan upacara. Pemasaran sarana upacara juga sudah muali terbuka dengan munculnya para pengepul yang menjajagkan produk kerajinan di tempat umum seperti di sengol, atau tempat keramaian lainnya dengan membawa mobil terbuka. Dengan adanya media sosial yang makin terbuka, banyak juga pemasaran sarana upacara yang dilakukan dengan online.

Perajin sangat jeli melihat selera masyarakat yang semakin berkembang, oleh sebab itu bentuk dan jenis seni kerajinan diciptakan sangat bervariasi dengan menawarkan berbagai kelebihan, baik model, fungsi, penampilan, dan kemasan. Keunggulan-keunggulan produk yang lebih artistik dan praktis digarap dengan cermat, untuk menarik para konsumen untuk membelinya. Penampilan yang menarik dan fungsi yang praktis menjadi incaran konsumen untuk memudahkan dalam penataan sesajen. Dulang atau wanci untuk sesajen gebogan telah banyak menawarkan bentuk yang menarik dan fungsi praktis. Sebelumnya penataan sesajen harus menggunakan lidi, tetapi sekarang sudah menggunakan alas lepas yang teklah dikemas dengan rapi. Dengan adanya alas ini, pemasangannya dapat dilakukan dengan mudah, cepat, rapi, dan sehat karena segala sarana banten tidak perlu ditusuk lagi dan hanya ditumpuk dengan teratur.

Teknologi berperan sangat besar pada perkembangan kerajinan sarana upacara, terutama berkaitan dengan penggunaan bahan dan teknis pengerjaan. Munculnya teknik reproduksi dalam penciptaan karya seni menyebabkan semua karya seni yang sifatnya massal dapat diciptakan dengan dengan mudah dan cepat. Selama ini bahan yang digunakan dari kayu dan harus dikerjakan secara manual, sekarang telah dapat direproduksi dengan menggunakan bahan feber glass.

Keunggulan dari penggunaan material ini, selain mudah dikerjakan, juga memiliki bobot yang sangat ringan dan sangat awet karena tidak bisa dimakan rayap. Ukiran ornamen juga dapat dimunculkan sangat menonjol dan rumit sesuai dengan contoh model yang digunakan.

Pesatnya perkembangan seni kerajinan sarana upaca- 

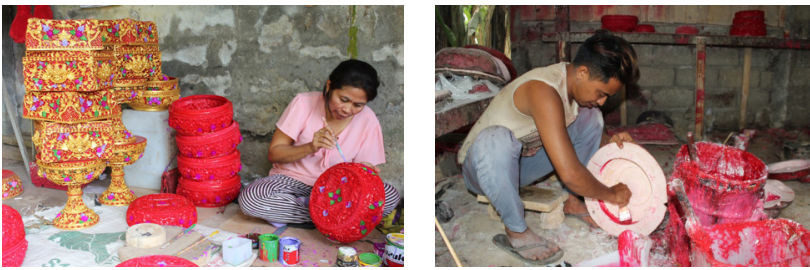

Gambar 1. Produksi seni kerajinan sarana upacara dengan teknik cetak fiber glass dan ukir kayu

(Sumber: Dokumen penulis, 2018)

ra tidak terlepas dari perhatian yang sangat besar masyarakat Bali dalam usaha mendukung wacana "Ajeg Bali" yaitu mempertahankan dan menjunjung tinggi budaya Bali yang unik dan adiluhung. Ajeg Bali adalah ajegnya pengamalan ajaran agama Hindu di Bali, atau kebudayaan Bali dan keindahan alamnya, tidak ada artinya bila tidak dijiwai oleh agama Hindu, oleh karena itu pengamalan ajaran agama Hindu merupakan hal yang sangat mendasar dalam mewujudkan ajeg Bali yang lestari (Titib, 2004: 1).36).Bali yang Ajeg bukan berarti mengajegan Bali yang mandeg, statis, dan stagnan, mengajegkan Bali yang rapuh dan lapuk, Bali yang mandul dan kolot, tetapi Bali yang Ajeg adalah Bali yang holistik, demokratis, yang utuh, aman, bersatu, adil makmur dan sejahtera, serta sehat lahir dan bhatin, sesuai dengan tujuan agama Hindu: "Moksartham Jagadhita Ya Ca Iti Dharma" yang perwujudannya merupakan hasil karya bersama (Kerepun, 2004: 47) .Ajeg Bali adalah Bali (Sekala-Niskala) yang didukung oleh orang Bali dengan kemajuan ilmu pengetahuan dan teknologi serta dilandasi oleh nilai-nilai dalam agama Hindu, artinya Bali yang ajeg adalah Bali yang berkembang sejalan dengan kemajuan IPTEKS dan kemajuan pola pikir orang Bali serta dilandasi oleh nilai-nilai agama Hindu. Dalam upaya memelihara keajegan Bali patutlah pelaku ajeg Bali melandasi diri dengan Tri Semaya yaitu: Atita (masa Lalu), Wartamana (masa sekarang, dan Nagata (masa yang akan datang) (Adiputra, 2005: 185). Masyarakat dan kebudayaan Bali adalah masyarakat dan budaya Hinduistis. Agama Hindu menjadi fondasi, akar, dan jiwa dari kebudayaan masyarakat Bali. Membicarakan ajeg Bali, juga sesungguhnya membicarakan "Ajeg Hindu”. Sepanjang agama Hindu masih ajeg di Bali, masih mempunyai pengaruh dominan, maka kebudayaan Bali akan tetap ajeg. Sebaliknya, kalau agama Hindu tidak dominan, maka keajegan masyarakat dan budaya Bali akan ada dalam tanda tanya besar (Pitana, 2004: 44).

Dalam usaha untuk mengamalkan ajeg Bali dalam kehidupannya sehari-hari, masyarakat melakukan berbagai aktivitas adat dan tradisi yang unik dan original, yang pada akhirnya memunculkan gaya hidup religius yaitu tiada hari tanpa kegiatan ritual. Animo masyarakat untuk melaksanakan ritual semakin meningkat, dan secara individu masyarakat mulai
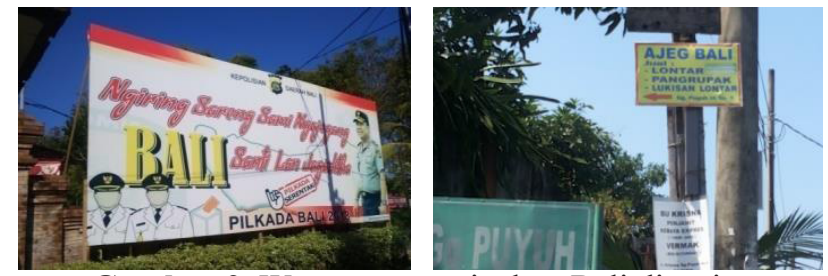

Gambar 2. Wacana mengajegkan Bali di setiap lini kehidupan masyarakat Bali

(Sumber: Dokumen penulis, 2018)

aktif untuk melakukan persembahyangan ke berbagai Pura yang tersebar luas di seluruh pulau Bali (Rekreasi religius). Rekreasi religius seakan sudah menjadi kebutuhan masyarakat yaitu mencari hiburan dengan kegiatan rohani.

Dinamika gaya hidup masyarakat Bali dilandasi oleh perubahan sosial masyarakat yang tidak terlepas dari pengaruh modernisasi terutama perkembangan pariwisata yang sangat pesat. Masyarakat Bali adalah masyarakat yang selektif dan sangat lihai dalam mengkolaborasi antara pengaruh modern dengan budaya tradisi yang kuat, menjadi sebuah tradisi baru yang berkembang di masyarakat. Masyarakat Bali yang sufel, fleksibel dan terbuka sangat cepat beradapdasi dengan budaya baru dan mengkemasnya menjadi budaya baru dan menyatu dengan budaya lama yang ada di masyarakat. Diperlukan sikap mental yang kuat dalam menghadapi globalisasi, sehingga sikap moral dan prilaku masih terjaga dengan baik (Sanjaya, 2002: 14).

Gaya hidup religius seakan sudah menjadi tradisi masyarakat Bali yang harus diikuti agar tidak dianggap ketinggalan jaman. Hal ini tidak semata pada penampilan sebuah upacara dengan segala perlengkapannya, tetapi juga penampilan diri seseorang dalam mengikuti upacara tersebut, terutama yang berhubungan dengan kaum wanita. Untuk melakukan persembahyangan mereka harus berpenampilan modis, dengan pakaian yang seksi dan menarik dengan polesan rias wajah yang menor. Gaya hidup religius ini banyak didorong oleh kehidupan ekonomi masyarakat yang semakin meningkat. Masyarakat menyadari bahwa apa yang telah didapat merupakan kemurahan Yang Maha Kuasa,oleh sebab itu sebagai umat beragama wajib untuk mengadakan persembahan sesuai dengan kemampuan, sehingga keseimbangan jasmani dan rohani akan dapat tercapai.

Tuntutan kebutuhan spiritual menjadi gaya hidup masyarakat yang diaktualisasikan dengan tindakan yang terkadang berlebihan, sehingga nilai spiritual sangat kecil dan pada akhirnya menonjolkan materialistis. Spiritual hanya sebagai balutan untuk menunjukan material yang berlebihan pada orang lain dengan pamer kekayaan dan kemewahan. Penampilan 

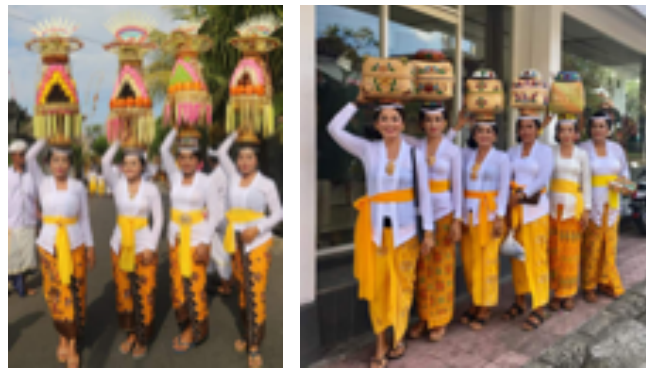

Gambar 3. Masyarakat selalu berusaha untuk menggunakan sarana upacara yang terbaru, terindah dan memiliki identitas Bali. (Sumber: Dokumentasi penulis, 2018)

menjadi utama dan segalanya dalam setiap melaksanakan perhelatan upacara dengan mengesampingkan inti sarinya. Menjadi sebuah fenomena baru, spiritual menjadi gaya hidup yang lebih menekankan seremonial dan bukan pada penghayatan isi dan nilai yang terkandung di dalamnya.

Kurangnya pemahaman masyarakat pada nilai-nilai ritual menyebabkan gaya hidup religius merambah pada semua lapisan masyarakat dan menjadi tradisi baru yang terus berkembang seiring waktu yang terus berjalan. Masyarakat seakan berlomba untuk menunjukan diri sebagai orang yang aktif dan produktif dalam menjalanjan gaya hidup religius. Setiap perhelatan upacara dilaksanakan dengan sungguh-sungguh terutama yang berhubungan dengan nilai profannya. Masyarakat juga sangat aktif untuk mengadakan persembahyangan ke berbagai pura yang berada di seluruh Bali dengan melakukan rekreasi religius. Gejala ini perlu diapresiasi dengan baik sebagai sebuah prilaku bhakti yang sangat suci dan mulia. Persoalannya adalah aktivitas ini dilaksanakan tidak dilandasi oleh niat yang murni, tetapi terkadang termotivasi oleh tujuan lain, serta tidak jarang karena didorong oleh ajakan orang lain dan bukan muncul dari hati sanubarinya.

Banyak masyarakat melaksanakan upacara besar dan mewah dengan mengutamakan penampilan dari pada kemurnian dan kesucian hati untuk menunjukan diri sebagai seseorang yang memiliki status sosial yang tinggi. Masyarakat kurang memahami bahwa dalam Itihasa dijelaskan upacara yang besar belum tentu memiliki nilai tinggi dibandingkan dengan upacara yang kecil namun inti. Sesungguhnya upacara yang bernilai tinggi adalah upacara yang dilakukan dengan tulus iklas (nekeng twas) dan hati yang bersih. Upacara yang dilakukan hanya diperuntukan pamer diri, lebih banyak keterikatannya pada ego pribadi, dan sebagai gaya hidup, maka upacara tersebut akan sia-sia tidak memiliki nilai apa-apa (Subawa, 2012: 125). Oleh sebab itu dalam melaksanakan upacara harus dilakukan sesuai dengan kemampuan dan ketulusan hati yang murni dan suci.

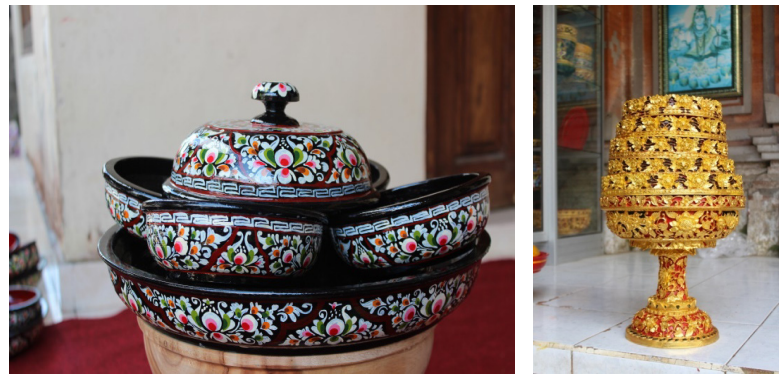

Gambar 4. Ornamen memberi nilai kemewahan Pada produk sarana upacara.

(Sumber: Dokumentasi penulis, 2018)

Munculnya gaya hidup religius pada masyarakat, pada sisi lain memberi peluang ekonomi pada masyarakat lainnya, terutama yang mengerjakan berbagai sarana pendukungnya seperti penjual kebaya, perajin sarana upacara, dan pedagang buah dan kue yang ada di pasar. Gaya hidup religius masyarakat memberi pengaruh yang sangat besar pada perajin untuk menyediakan berbagai kebutuhan upacara, baik yang berhubungan dengan sarana upacara itu sendiri maupun berbagai perabotan sebagai tempat sesajen.

Gaya hidup religius memerlukan berbagai bentuk dan jenis sarana upacara yang unik dan artistik. Masyarakat akan selalu menggunakan sarana upacara yang indah dan menarik sebagai sebuah persembahan yang suci dan murni. Masyarakat akan merasa sempurna di hadapan Tuhan apabila telah mempersembahkan yang terbaik dan terindah pada Yang Maha Kuasa, oleh sebab itu masyarakat selalu berusaha untuk mendapatkan sarana upacara yang terbaru, terindah dan memiliki identitas Bali. Selain untuk persembahan, pemanfaatan berbagai sarana upacara juga digunakan dalam usaha melestarikan budaya Bali yang adiluhung agar tidak tergerus oleh pengaruh globalisasi yang semakin bebas. Mencintai produk kerajinan lokal merupakan bagian untuk ikut melestarikan budaya Bali yang adiluhung agar tetap ajeg dan kokoh

Meningkatnya kebutuhan masyarakat akan berbagai sarana upacara, memberi peluang yang sangat terbuka bagi para perajin untuk meningkatkan kreativitasnya menciptakan karya-karya baru yang original dan memiliki identitas lokal yang sangat kuat. Inovasi perajin yang tinggi, menjadikan bentuk dan jenis kerajinan sarana upacara bermunculan dengan menawarkan stail dan gaya yang bervariatif. Berbagai model sarana upacara tercipta, baik dalam bentuk ukiran kayu, anyaman, cetakan, maupun rakitan. Hal yang sangat menarik adalah pemanfaatan ornamen menjadi suatu yang sangat dominan sebagai penambah artistik yang diterapkan baik dalam bentuk ukiran langsung, cetakan, batik, maupun sunggingan. 

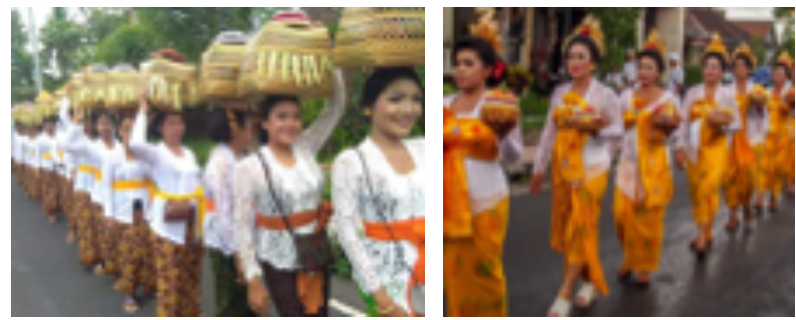

Gambar 5. Keanekaragaman produk sarana upacara digunakan dalam kegiatan upacara adat dan agama. (Sumber: Dokumentasi penulis, 2018)

Ornamen menjadi bagian yang sangat penting dalam penciptaan sarana upacara, ini sebagai tanda bahwa orang Bali sangat mencintai seni dan keindahan. Keyakinan masyarakat Bali bahwa sebuah produk akan memiliki nilai seni yang tinggi apabila telah dihiasi dengan ornamen, dan belum dianggap sebuah karya seni apabila produk tersebut tidak dihiasi dengan ornamen. Oleh sebab itu, tiada produk yang terlepas dari sentuhan ornamen dengan motif deformatif maupun realis. Pembubuhan ornamen pada sebuah produk tidak semata penambah keindahan, tetapi juga memberikan nilai yang sangat tinggi, baik secara ekonomi maupun status sosial pemakainya. Ornamen memberi nilai kemewahan pada suatu produk maupun pemakainya, sehingga ornamen selalu menjadi perhatian serius oleh penciptanya.

Secara fungsional, berbagai produk sarana upacara telah menawarkan fungsi yang sangat praktis, tetapi belum dianggap sempurna apabila tidak dibubuhi dengan ornamen. Berbagai teknik digunakan untuk membubuhkan ornamen pada produk sarana upacara, tergantung dari pada media yang digunakan, seperti teknik ukiran, sulaman, sunggingan, lukis, kolase, cetak, maupun sablon. Selain motif hias yang digunakan, teknik ornamen juga dapat memberikan bobot yang berbeda pada sebuah produk. Teknik manual akan memiliki nilai yang lebih tingggi dari pada teknik sablon maupun cetak, karena adanya sentuhan jiwa penciptanya. Sarana upacara dengan ukiran langsung akan lebih berbobot dengan ukiran yang direproduksi, demikian juga ornamen dengan teknik sunggingan dan lukis akan jauh lebih bernilai dari ornamen dengan teknik sablon. Secara umum masyarakat memiliki kemampuan untuk menilai hal ini, sehingga masyarakat akan menyesuaikan dengan kemampuan dan keinginannya dalam memilih sarana upacara yang digunakan.

Ornamen menjadi bagian yang tak terpisahkan dari gaya hidup religius masyarakat, ini dibuktikan dengan antusias masyarakat dalam memilih sarana upacara dengan pemakaian ornamen yang mewah dan elegan. Masyarakat akan merasa bangga dan percaya diri apabila menjunjung sarana upacara dengan or- namen yang bagus dan mewah, karena secara tidak langsung akan mendukung penampilan dan status soaialnya. Masyarakat yang menggunakan sarana upacara yang mewah dengan ornamen yang unik, dapat dipastikan bahwa mereka dari golongan status sosial yang tinggi, baik kastanya maupun materinya. Status sosial masyarakat akan selalu dinilai dari sarana yang digunakan, sehingga masyarakat yang memiliki jiwa ingin dipuji dan disanjung (belog ajum) akan selalu memperhitungkan sarana apa yang harus mereka gunakan.

Tuntutan masyarakat konsumen pada tingginya nilai ornamen menyebabkan dominasi ornamen pada sebuah produk sangat tinggi. Banyak produk yang dihiasi dengan ornamen secara berlebihan, dengan tidak menyisakan ruang kosong. Produk dibalut dengan ornamen secara utuh sehingga estetika bentuk menjadi hilang. Penempatan ornamen juga sering tidak pada tempatnya, sehingga mengganggu fungsi praktisnya. Masyarakat banyak yang menyukai produk sarana upacara semacam ini sebagai sesuatu yang sangat mewah dan elegan. Mereka beranggapan bahwa sebuah produk yang kaya dengan ornamen adalah karya yang berbobot dan mernilai tinggi dan sangat tepat sebagai media persembahan.

Uraian di atas menjelaskan bahwa betapa penting dan utamanya peran seni kerajinan dalam mendukung segala aspek kehidupan masyarakat, baik sebagai sarana dalam berbagai aktivitas, juga sebagai media dalam mendukung ekonomi masyarakat serta peningkatan devisa negara. Kriya dan seni kerajinan juga memiliki nilai yang sangat tinggi sebagai karya seni budaya yang adiluhung dengan identitas yang sangat kuat pada masing-masing daerah tempat seni kriya dan kerajinan tersebut berkembang.

\section{SIMPULAN}

Gaya hidup religius berpengaruh sangat besar pada produksi seni kerajinan sarana upacara yang ada di Bali. Gaya hidup religius yang ditandai dengan meningkatnya animo masyarakat dalam melaksanakan aktivitas adat dan agama, membutuhkan berbagai sarana upacara yang indah dan menarik dengan berbagai bentuk dan fungsi. Sarana upacara selain sebagai tempat sesajen dalam persembahan, juga berfungsi sebagai pendukung penampilan diri pada orang yang memakainya. Masyarakat akan percaya diri apabila menggunakan sarana upacara yang mewah dan artistik untuk melaksanakan persembahan.

Sarana upacara memiliki peranan yang sangat besar untuk mendukung gaya hidup religius masyarakat, oleh sebab itu sarana upacara tidak saja memenuhi 
fungsi praktis, tetapi juga sering dimanfaatkan sebagai fungsi sosial untuk menunjukan stratifikasi status sosial dalam masyarakat. Banyak masyarakat yang memilih sarana upacara yang mewah dan elegan, di samping ingin mempersembahkan yang terbaik pada Yang Kuasa, tetapi juga ingin menunjukan jati diri sebagai orang yang kaya pada masyarakat lain. Masyarakat akan sangat percaya diri apabila dalam mengusung sesajen menggunakan sarana upacara yang mewah dan gemerlap sebagai pertanda kehidupan mereka sudah mapan.

Untuk mendukung gaya hidup religius, berbagai jenis dan bentuk sarana upacara telah tercipta dengan menawarkan berbagai keindahan dan kepraktisan dalam pemakaiannya. Bahan yang digunakan juga cukup bervariasi dengan teknik pengerjaan yang manual atau menggunakan teknologi. Didukung dengan ditemukannya teknik reproduksi, penciptaan seni kerajinan sarana upacara berkembang sangat pesat dengan bentuk yang unik dan menarik. Selain penciptaan dengan teknik reproduksi, banyak sarana upacara diciptakan dengan teknik anyaman yang dihiasi dengan ornamen yang sangat artistik. Ornamen yang sangat unik akan memberikan nilai yang cukup tinggi pada sarana upacara,baik nilai estetik maupun ekonomi.

\section{DAFTAR RUJUKAN}

Adiputra, Gede Rudia, 2004,“Asih-Punia-Bhakti Pilar Spirit Ajeg Bali, Dialog Ajeg Bali, Paramita, Surabaya.

Anas, Biranul, 1999, "Kriya dan Pemasarannya Suatu Tujuan Ke Dalam Pariwisata" Semiloka Seni Kriya dan Pariwisata, Ambarukmo, Yogyakarta.

Gunawan, Daddi H, 2014, Perubahan Sosial di Pedesaan Bali, Marjin Kiri,Tangerang.

Gustami SP., 1991, "Seni Kriya Indonesia: Dilema Pembinaan dan Pengembangannya", Pidato Ilmiah pada Dies Natalis VII ISI Yogyakarta.

Kerepun, Made, Kembar, 2004,"Analisis SWOT dalam strategi mencapai dan MemeliharaAjeg Bali", Dialog Ajeg Bali, Paramita Surabaya.

Moleong, Lexy, J, 2013, Metodologi Penelitian Kualitatif, PT Remaja Rosdakarya,

Bandung.

Piliang, Yasraf Amir, 2011, Dunia Yang Dilipat: Tamasya melampaui Batas-Batas

Kebudayaan, Bandung.
Pitana, I Gede, 2004,"Bali Yang Ajeg Adalah Bali Yang Berubah" Dialog Ajeg Bali,

Paramita Surabaya.

Sanjaya, IGMA, 2002, Mengangkat Nilai-nilai Agama dalam Menghadapi Globalisasi, Paramita, Surabaya.

Soethama, Gde Aryantha, 2011, Jangan Mati di Bali, Kompas, Jakarta,

Subawa, I Gede, 2012, Reformasi Ritual, Mentradisikan Agama bukan Mengagamakan Tradisi, Pustaka Bali Post, Denpasar,.

Titib, I Made, 2004, “ Ajeg Bali Perspektif Pengamalan Agama Hindu", Dialog Ajeg Bali, Paramita Surabaya.

Widana, I Gusti Ketut, 2012, Penjor Lebay, Pustaka Bali Post, Denpasar. 